Praca poglądowa/Review

\title{
Ponatynib w leczeniu przewlekłej białaczki szpikowej i ostrej białaczki limfoblastycznej z chromosomem Filadelfia
}

\section{Ponatinib in therapy of chronic myeloid leukemia and Philadelphia positive acute lymphoblastic leukemia}

\author{
Tomasz Sacha* \\ Katedra i Klinia Hematologii Collegium Medicum Uniwersytetu Jagiellońskiego, Kierownik: \\ prof. dr hab. med. Aleksander B. Skotnicki, Kraków, Polska
}

IN F ORMACJE O ARTYKULE

Historia artykułu:

Otrzymano: 03.02.2016

Zaakceptowano: 12.04 .2016

Dostępne online: 22.04 .2016

\section{Słowa kluczowe:}

- przewlekła białaczka szpikowa

- ostra białaczka limfoblastyczna Ph+

- mutacja T315I

- ponatynib

- wskazania

- leczenie

Keywords:

- Chronic myeloid leukemia

- Acute lymphoblastic leukemia Ph+

- T315I mutation

- Ponatinib

- Indications

- Therapy

\begin{abstract}
A B S T R A C T
Ponatinib is a third generation tyrosine kinase inhibitor (TKI) active against wild type and mutant bcr/abl tyrosine kinase (including T315I). Ponatinib is approved for the treatment of adult patients with T315I mutation detected in CML (all phases) and in Ph+ ALL, for CML patients who are resistant to dasatinib or nilotinib and patients with Ph+ ALL who are intolerant or resistant to dasatinib and for whom subsequent imatinib treatment is not an optimal therapy. In phase II registration study (PACE), 267 patients with CML in chronic phase (CP), 83 in accelerated (AC) and 94 patients in blastic phase (BP) of CML or $\mathrm{Ph}+\mathrm{ALL}$ were enrolled. T315I mutation was detected in 64, 18 and 46 patients, respectively. Two or more or three or more TKIs were used before ponatinib in $93 \%$ and $58 \%$ of patients, respectively for median period of 16.7 months. Major cytogenetic response (MCyR) by 12 months was achieved in 59\% of CP CML patients (median follow-up 36 months), and major hematological response (MaHR) by 6 months in 55\% of AC CML patients, and in $34 \%$ of BP CML and Ph+ALL patients (median follow-up 15.16 and 6 months, respectively). Efficacy of ponatinib as a first-line treatment for CP CML patients was shown in phase II and III trials. Serious adverse reactions have been reported with ponatinib, including vascular occlusion, heart failure and hepatotoxicity. Ponatinib is a valuable treatment option for patients with CML and Ph+ALL resistant or intolerant to previous therapy with TKIs and those with T315I mutation.
\end{abstract}

() 2016 Polskie Towarzystwo Hematologów i Transfuzjologów, Instytut Hematologii i Transfuzjologii. Published by Elsevier Sp. z o.o. All rights reserved.

* Adres do korespondencji: Katedra i Klinia Hematologii UJCM w Krakowie, ul. Kopernika 17, 31-501 Kraków, Polska.

Adres email: sachatom@gmail.com.

http://dx.doi.org/10.1016/j.achaem.2016.04.002

0001-5814/@ 2016 Polskie Towarzystwo Hematologów i Transfuzjologów, Instytut Hematologii i Transfuzjologii. Published by Elsevier Sp. $\mathrm{z}$ o.o. All rights reserved. 


\section{Wstęp}

Poznanie kluczowej roli genu BCR/ABL1 kodującego kinazę tyrozynową bcr/abl w powstawaniu i rozwoju przewlekłej białaczki szpikowej (PBSz) [1] umożliwiło opracowanie inhibitorów kinaz tyrozynowych (IKT). Ich wprowadzenie do leczenia PBSz całkowicie zmieniło rokowania pacjentów [2], którzy osiągają 5-letnie całkowite przeżycie (OS) w odsetku (85\%) zbliżonym do ogólnej populacji [3]. Wykrywana u ok. 25\% chorych na PBSz pierwotna lub wtórna oporność na leczenie imatynibem [4] była stymulacją dla badań nad inhibitorami kinaz tyrozynowych kolejnych generacji. Obecność mutacji punktowych domeny genu ABL stanowi przyczynę ok. 50\% przypadków wtórnej oporności na leczenie imatynibem [5]. Zastosowanie w takiej sytuacji inhibitorów kinaz tyrozynowych 2. generacji (IKT2G) - nilotynibu, dazatynibu lub bosutynibu daje możliwość uzyskania całkowitej odpowiedzi cytogenetycznej (CCyR) u ok. 40-60\% chorych [6], jednak u około połowy $\mathrm{z}$ nich $\mathrm{w}$ trakcie dalszej terapii rozwija się oporność lub nietolerancja powyższego leczenia [7-9]. Żaden z powyżej wspomnianych IKT nie przełamuje oporności związanej z mutacją T315I domeny genu ABL [10] wykrywanej u ok. 20\% chorych z opornością [11]. Wrażliwość in vitro niektórych częściej występujących mutacji domeny genu BCR-ABL1 na stosowane IKT przedstawiono w tabeli I. Ponatinib (Iclusig ${ }^{\circledR}$ ) jest silnym inhibitorem kinazy bcr/abl 3. generacji, zdolnym do przyłączania się z wysokim powinowactwem zarówno do dzikiej, jak i zmutowanej cząsteczki bcr/abl [12]. W jego strukturze chemicznej (Ryc. 1) występuje potrójne wiązanie między dwoma atomami węgla, które wystaje z purynowego szkieletu i umożliwia poprzez tworzenie wiązań van der Waalsa przyłączanie się leku do izoleucyny w pozycji 315 zmutowanej cząsteczki bcr/abl [4, 5]. Poniższy artykuł przybliża charakterystykę farmakodynamiczną, farmakokinetykę, skuteczność kliniczną i profil bezpieczeństwa ponatynibu u chorych $\mathrm{w}$ fazie przewlekłej (FP), akceleracji (FA) i kryzy blastycznej (KB) PBSz oraz z ostrą białaczką limfoblastyczną z chromosomem Filadelfia $(\mathrm{ALLPh}+)$.

Tabela I - Wrażliwość in vitro niektórych częściej występujących mutacji domeny genu BCR-ABL1 na imatynib, nilotynib, dazatynib, bosutynib i ponatynib [6]

Table I - In vitro sensitivity of some of the more frequent BCR-ABL1 kinase domain mutants to imatinib, nilotinib, dasatinib, bosutinib, and ponatinib [6]

\begin{tabular}{|c|c|c|c|c|c|}
\hline BCR-ABL1 & $\begin{array}{c}\text { Imatynib } \mathrm{IC}_{50}, \\
\text { zakres (nM) }\end{array}$ & $\begin{array}{l}\text { Nilotynib } \mathrm{IC}_{50}, \\
\text { zakres (nM) }\end{array}$ & $\begin{array}{c}\text { Dazatynib } \text { IC }_{50}, \\
\text { zakres (nM) }\end{array}$ & $\begin{array}{c}\text { Bosutynib } \mathrm{IC}_{50} \\
\text { (nM) }\end{array}$ & $\begin{array}{c}\text { Ponatynib } \mathrm{IC}_{50} \\
\text { (nM) }\end{array}$ \\
\hline Niezmutowany & $260-678$ & $<10-25$ & $0,8-1,8$ & 41,6 & 0,5 \\
\hline $\mathrm{M} 244 \mathrm{~V}^{*}$ & $1600-3100$ & $38-39$ & 1,3 & 147,4 & 2,2 \\
\hline L248V & $1866-10000$ & $49,5-919$ & 9,4 & $\mathrm{BD}$ & $\mathrm{BD}$ \\
\hline G250E* & 1350 to $>20000$ & $48-219$ & $1,8-8,1$ & 179,2 & 4,1 \\
\hline Q252H & $734-3120$ & $16-70$ & $3,4-5,6$ & 33,7 & 2,2 \\
\hline Y253F & $>6400-8953$ & $182-725$ & $6,3-11$ & 40 & 2,8 \\
\hline $\mathrm{Y}_{253 \mathrm{H}^{*}}$ & $>6400-17700$ & $450-1300$ & $1,3-10$ & BD & 6,2 \\
\hline E255K* & $3174-12100$ & $118-566$ & $5,6-13$ & 394 & 14 \\
\hline E255V & $6111-8953$ & $430-725$ & $6,3-11$ & 230,1 & 36 \\
\hline D276G & 1147 & 35,3 & 2,6 & 25 & $\mathrm{BD}$ \\
\hline E279K & 1872 & $36,5-75$ & 3 & 39,7 & $\mathrm{BD}$ \\
\hline V299L & $540-814$ & 23,7 & $15,8-18$ & 1086 & $\mathrm{BD}$ \\
\hline F311L & $480-1300$ & 23 & 1,3 & $\mathrm{BD}$ & $\mathrm{BD}$ \\
\hline T315I* & $>6400$ do $>20000$ & 697 do $>10000$ & 137 do $>1000$ & 1890 & 11 \\
\hline T315A & 125 & $\mathrm{BD}$ & 760 & $\mathrm{BD}$ & 1,6 \\
\hline F317L* & $810-7500$ & $39,2-91$ & $7,4-18$ & 100,7 & 1,1 \\
\hline F317V & 500 & 350 & $\mathrm{BD}$ & $\mathrm{BD}$ & 10 \\
\hline M351T* & $880-4900$ & $7,8-38$ & $1,1-1,6$ & 29,1 & 1,5 \\
\hline F359V* & $1400-1825$ & $91-175$ & $2,2-2,7$ & 38,6 & 10 \\
\hline V379I & $1000-1,630$ & 51 & 0,8 & $\mathrm{BD}$ & $\mathrm{BD}$ \\
\hline L384M ${ }^{*}$ & $674-2800$ & $39-41,2$ & 4 & 19,5 & $\mathrm{BD}$ \\
\hline L387M & $1000-1100$ & 49 & 2 & $\mathrm{BD}$ & $\mathrm{BD}$ \\
\hline H396 ${ }^{*}$ & $1750-5400$ & $41-55$ & $1,3-3$ & 33,7 & $\mathrm{BD}$ \\
\hline H396P & $850-4300$ & $41-43$ & $0,6-2$ & 18,1 & 1,1 \\
\hline F486S & $2728-9100$ & $32,8-87$ & 5,6 & 96,1 & $\mathrm{BD}$ \\
\hline \multicolumn{6}{|c|}{ Stężenie leku w osoczu } \\
\hline $\mathrm{C}_{\min }$ & $2062 \pm 1334$ & $1923 \pm 1233$ & $5,5 \pm 1,4$ & $268(30-1533)$ & $64,3 \pm 29,2$ \\
\hline $\mathrm{C}_{\max }$ & $4402 \pm 1272$ & $2329 \pm 772$ & $133 \pm 73,9$ & $392(80-1858)$ & $145,4 \pm 72,6$ \\
\hline
\end{tabular}

Maksymalne stężenie hamujące 50\% wzrost kolonii ( $\mathrm{IC}_{50}$ - the half maximal inhibitory concentration) BD - brak danych. W tabeli zamieszczono mutacje BCR-ABL1, dla których określono wartość IC50 dla przynajmniej 2 IKT. Stężenie leku w osoczu jest podaną wartością średnią \pm odchylenie standardowe dla dawek imatinibu: $400 \mathrm{mg} / \mathrm{d}$, nilotynibu $300 \mathrm{mg} 2 \mathrm{x} \mathrm{d}$, dazatynibu $100 \mathrm{mg} / \mathrm{d}$, ponatynibu $45 \mathrm{mg} / \mathrm{d}$ i bosutynibu $500 \mathrm{mg} / \mathrm{d}$. 


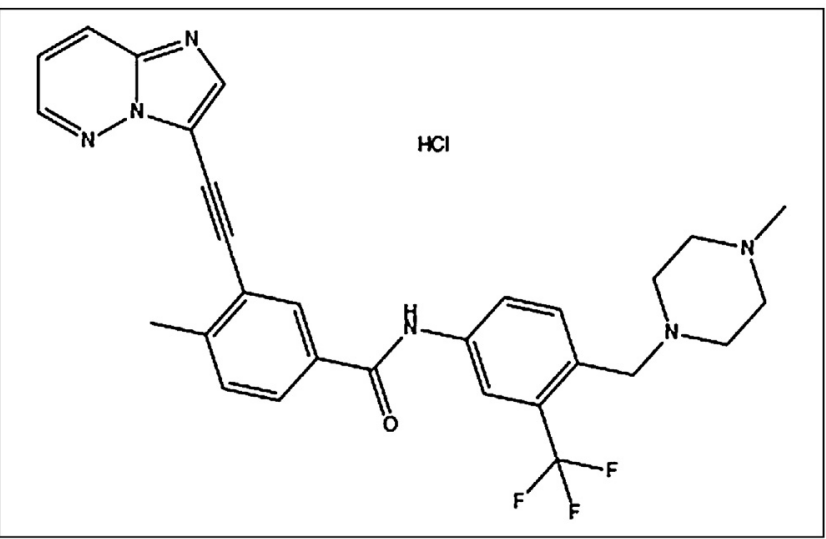

Ryc. 1 - Struktura chemiczna ponatynibu

Fig. 1 - Chemical structure of ponatinib

\section{Właściwości farmakodynamiczne i farmakokinetyczne ponatynibu}

$\mathrm{W}$ badaniach in vitro ponatynib hamuje 50\% aktywności niezmutowanej kinazy $\mathrm{ABL}\left(\mathrm{IC}_{50}\right.$ : Inhibitory Concentration $\left.{ }_{50}\right)$ w stężeniu 0,37 nmol/L, kinazy $A B L \quad z$ mutacją T315I w stężeniu 2,0 nmol/L oraz aktywność kinazy ABL $\mathrm{z}$ innymi klinicznie istotnymi mutacjami w stężeniach 0,30-0,44 nmol/L) [13]. Ponatynib jest także inhibitorem kinaz: FLT3, KIT, RET, TIE2 oraz kinaz tyrozynowych $\mathrm{z}$ rodziny receptora efryny (EPH), jak: FGFR, PDGFR, SRC oraz VEGFR, dla których wartość $\mathrm{IC}_{50}$ wynosi $20 \mathrm{nmol} / \mathrm{L}$ [13-15]. Ponatinib nie blokuje kinaz $\mathrm{z}$ rodziny Aurora, kinazy receptora insuliny ani zależnej od cyklin kinazy 2/cykliny E [13]. Ponatynib najsilniej blokuje wzrost kolonii komórek z mutacjami: T315I, E255K oraz E255V (wartości IC 50 odpowiednio: 11, 14 i 36 nmol/L) [13]. Ponatynib w stężeniu $40 \mathrm{nmol} / \mathrm{L}$ skutecznie hamuje wzrost opornych komórek PBSz; w trakcie jego stosowania nie pojawił się żaden klon komórek z mutacją wywołującą ich oporność [13]. Maksymalne stężenie we krwi ( $\left.C_{\max }\right)$ osiągane jest po 4-6 godzin od doustnego przyjęcia leku na czczo [16], a stabilne stężenie ponatynibu po tygodniu jego stosowania [15]. W badaniu I fazy zaobserwowano, że stosowanie dawki $\geq 30 \mathrm{mg} / \mathrm{d}$ skutkuje osiągnięciem stabilnego stężenia leku wystarczającym dla zahamowania wzrostu opornych klonów komórek PBSz [17]. Czas połowicznej eliminacji ponatynibu przy dawkowaniu $45 \mathrm{mg} / \mathrm{d}$ wynosi 22 godziny [16]. Stosowanie ponatynibu $\mathrm{u}$ chorych $\mathrm{z}$ umiarkowanym lub ciężkim upośledzeniem czynności wątroby może doprowadzić do znaczącego zwiększenia jego stężenia w osoczu. Nie wykazano jak dotąd wpływu upośledzenia czynności nerek na farmakokinetykę ponatynibu, zalecana jest jednak ostrożność w stosowaniu tego leku u chorych $\mathrm{z}$ klirensem kreatyniny $<50 \mathrm{~mL} / \mathrm{min}$ oraz u chorych z krańcową niewydolnością nerek [14, 15].

\section{Możliwe interakcje ponatynibu}

Ponatynib jest substratem podjednostki CYP3A4/5 i w mniejszym stopniu podjednostek CYP2C8 oraz CYP2D6 cytochromu P450 [14]. Jego jednoczesne podawanie $\mathrm{z}$ ketokonazolem (silnym inhibitorem CYP3A4) powoduje wzrost $\mathrm{AUC}_{\infty}$ i wartości $C_{\max }$ dla ponatynibu odpowiednio o $78 \%$ i $47 \%$ [18]. Zaleca się szczególną ostrożność przy jego stosowaniu wraz z umiarkowanymi lub silnymi inhibitorami podjednostki CYP3A4 cytochromu P450 (np. sok grejpfrutowy, ketokonazol, klarytromycyna, nefazodon, ritonawir), a w sytuacji konieczności jego podawania z silnymi inhibitorami CYP3A4 redukcję dawki do $30 \mathrm{mg} / \mathrm{d}$ [14]. Umiarkowane lub silne induktory CYP3A4 (n.p. fenobarbital, ryfampicyna, karbamazepina) mogą zmniejszyć stężenie ponatynibu w osoczu w nieznanym zakresie, podobnie jak leki zwiększające $\mathrm{pH}$ soku żołądkowego (blokery pompy protonowej, receptora $\mathrm{H}_{2}$, leki zobojętniające) $[14,15]$, dlatego jednoczesne stosowanie powyższych leków z ponatynibem należy roważyć, jeśli korzyści z ich podawania przewyższają ryzyko związane z leczeniem PBSz jego suboptymalną dawką. Ponatynib nie jest substratem molekuł lekooporności (p-gp, BRCP), jest jednak ich inhibitorem i może zwiększać stężenie leków będących substratami p-gp (n.p. digoksyna, prawastatyna) lub BRCP (n.p. metotrexat, sulfosalazyna), dlatego zalecane jest ścisłe monitorowanie chorych otrzymujących jednocześnie jeden $\mathrm{z}$ tych leków wraz z ponatynibem $[14,15]$.

\section{Wyniki badań klinicznych nad skutecznością ponatynibu}

\section{Badania I fazy u chorych na PBSz i ALLPh(+)}

W badaniu I fazy 60 chorym na oporną na leczenie PBSz (w tym 43 na PBSz w FP, 9 na PBSz w FA i 8 na PBSz w KB) i 5 chorym na ALL $\mathrm{Ph}(+)$ podawano od $2 \mathrm{mg}$ do $60 \mathrm{mg}$ ponatynibu dziennie. Po średnim okresie obserwacji 73 tygodni u chorych na PBSz w FP całkowitą odpowiedź hematologiczną (CHR) odnotowano u 98\% pacjentów (u wszystkich z mutacją T315I), większą odpowiedź cytogenetyczną (MCyR) u 72\% (u 92\% chorych z mutacją T315I), a większą odpowiedź molekularną (MMR) u 44\%. Po 34 miesiącach średniego okresu obserwacji chorych na PBSZ w FP CHR utrzymała się u 72\%, a MCyR u 51\% pacjentów. Spośród 22 chorych na PBSz w FA lub KB albo ALLPh(+) po średnim okresie obserwacji 13 tygodni MaHR uzyskano u 36\%, a MCyR u 32\% pacjentów [11].

\section{Toksyczność ponatynibu w badaniu I fazy}

Nie stwierdzono objawów toksyczności ograniczającej dawkę w grupie chorych otrzymujących $30 \mathrm{mg} / \mathrm{d}$ ponatynibu. U chorych leczonych dawką $45 \mathrm{mg} / \mathrm{d}$ było nią zaczerwienienie skóry, a u pacjentów otrzymujących $60 \mathrm{mg} / \mathrm{d}$ ponatynibu było nią zwiększenie stężenia enzymów trzustkowych (lipazy, amylazy lub obu) i zapalenie trzustki u 4 chorych, zwiększenie stężenia ALT i AST w 3 stopniu nasilenia u 1 chorego i zmęczenie w 3 stopniu nasilenia $u$ jednego chorego. Zapalenie trzustki wystąpiło u 11 chorych (u 8 jako ciężkie zdarzenie niepożądane), a wzrost stężenia lipazy albo amylazy dodatkowo u 7 chorych. Czas do wystąpienia zapalenia trzustki lub zwiększenia stężenia amylazy lub lipazy oraz stopień nasilenia tych zaburzeń był zależny od dawki i wahał 
się od 6,5 do 40 dni. U 9 spośród 11 chorych pancreatitis wystąpiło jeden raz, u 2 chorych odnotowano po 3 epizody zapalenia. U 7 chorych w wywiadzie występowały czynniki ryzyka: spożywanie alkoholu $(n=3)$, cukrzyca $(n=3)$ i epizod pancreatitis $(\mathrm{n}=1)$. U większości przebieg zapalenia był samoograniczający z ustąpieniem po 6 dniach (w 13 spośród 15 przypadków). Ponatynib odstawiono całkowicie u 2 chorych $\mathrm{z}$ powodu zapalenia trzustki i u 1 pacjenta $\mathrm{z}$ powodu wzrostu stężenia lipazy, u pozostałych możliwa była kontynuacja leczenia. Najczęstszymi niehematologicznymi działaniami niepożądanymi były zmiany skórne (np. zaczerwienienie, zapalenie skóry, suchość skóry) i objawy konstytucjonalne (np. bóle stawów, zmęczenie, nudności), które występowały najczęściej w 1. lub 2. stopniu nasilenia. Wśród chorych na PBSz w FP toksyczność hematologiczna w stopniu 3. lub wyższym wystąpiła pod postacią małopłytkowości u $28 \%$, neutropenii u 14\% i niedokrwistości u 2\% pacjentów. Nie odnotowano istotnego przedłużenia okresu repolaryzacji komór serca pod wpływem dawek 30, 45 lub 60 mg/d, jednak nie wykonano szczegółowej analizy wpływu tego leku na długość trwania odcinka QT i takiego efektu nie można wykluczyć [11, 19]. Na podstawie wyników badań I fazy ustalono, że w badaniach klinicznych kolejnych faz stosowana będzie dawka $45 \mathrm{mg} / \mathrm{d}$ ponatynibu [11].

Badania II fazy u chorych na PBSz i ALLPh(+) z opornością lub nietolerancją dotychczasowego leczenia

Wyniki badania PACE

W przebiegu wieloośrodkowego badania II fazy (PACE) ponatynib stosowano w dawce $45 \mathrm{mg} / \mathrm{d}$ w leczeniu 449 dorosłych chorych, w tym u 270 na PBSz w fazie przewlekłej, u $85 \mathrm{w}$ fazie akceleracji, u $62 \mathrm{w}$ fazie kryzy blastycznej oraz u 32 chorych na ALL $\mathrm{Ph}(+)$ opornych lub nietolerujących leczenia dazatynibem lub nilotynibem albo u tych, u których wykryto mutację T315I w przebiegu terapii jakimkolwiek IKT [20]. W badanej grupie chorych znaleźli się pacjenci, którzy otrzymywali uprzednio jeden (7\%), dwa (36\%), trzy (52\%) lub cztery (4\% chorych) IKT. Pierwotnym celem badania $\mathrm{u}$ chorych z FP PBSz było uzyskanie w pierwszych 12 miesiącach leczenia większej odpowiedzi cytogenetycznej (MCyR), a u chorych z FA lub KB uzyskanie w pierwszych 6 miesiącach terapii większej odpowiedzi hematologicznej (MaHR). Średni okres leczenia stosowanego przed badaniem $\mathrm{u}$ chorych z FP PBSz lub FA PBSz wynosił 7 lat, z KB PBSz 4 lata, a na ALLPh(+) 2 lata [20]. Chorzy byli leczeni średnio trzema IKT [21]; przynajmniej dwa IKT otrzymało 93\%, a przynajmniej trzy $57 \%$ chorych. Wśród pacjentów leczonych uprzednio dazatynibem lub nilotynibem $(n=427)$ przeważali chorzy z opornością (88\%). Do najczęściej wykrywanych mutacji przy rozpoczęciu badania należały: T315I (u 29\%), F317L (u 8\%), E255K (u 4\%), F359V (u 4\%) oraz G250E (u $3 \%$ chorych). W sumie mutacje wykryto u $55 \%$ chorych z FP PBSz (z czego dwie u 26 spośród 267), u 7\% spośród 83 chorych z FA PBSz, u $16 \%$ spośród 62 chorych z KB PBSz i u $28 \%$ spośród 32 chorych na ALL Ph(+) [21].

\section{Wyniki u chorych na PBSz w fazie przewlekłej}

Pierwotny cel badania PACE (uzyskanie MCyR w pierwszych 12 miesiącach leczenia) został osiągnięty u 59\% chorych (tabela II przedstawia uzyskane odpowiedzi cytogenetyczne i molekularne). [22]. Średni czas do uzyskania MCyR i CCyR wynosił 2,8 miesiąca, a MMR 5,5 miesiąca. MCyR utrzymywała się przez 24 miesiące u 87\% chorych [22]. MMR utrzymywała się przez 12 miesięcy u 81\% chorych [20]. Odsetki przeżycia wolnego od progresji (PFS) i całkowitego (OS) wyniosły po 12 miesiącach $80 \%$ i 94\%, a po 24 miesiącach odpowiednio 67\% i 86\% [20, 22]. Odsetek uzyskanych odpowiedzi cytogenetycznych zależał od średniej przyjmowanej dawki leku (zależność istotna statystycznie (Tab. III) [24]. Po 4 latach obserwacji leczenia zaprzestało $58 \%$ pacjentów, najczęstszą przyczyną były działania niepożądane (18\%) [25]. Zpowodu progresji choroby leczenie przerwało $9,6 \%$, a $z$ powodu braku skuteczności $6 \%$ chorych. Spośród 56 chorych, którzy zakończyli udział w badaniu, nową mutację wykryto u 5, a u innych 5 obecna wcześniej mutacja znikła. Nie wykryto żadnej mutacji, która byłaby przyczyną oporności na ponatynib [20]. Lepsze odpowiedzi odnotowano u młodszych chorych, otrzymujących większą średnią dawkę leku i leczonych mniejszą liczbą IKT przed kwalifikacją do badania [20, 25] (Tab. IV).

\section{Wyniki u chorych na PBSz w fazie akceleracji}

Wyniki analizowane po 15 miesięcznej obserwacji w badaniu PACE u chorych na PBSz w FA, PBSz w KB i na ALLPh(+) zestawiono $\mathrm{w}$ tabeli V. MaHR uzyskano średnio po 3 tygodniach, a MCyR po 3,7 miesiąca leczenia. Średni czas trwania MaHR wynosił 12 miesięcy, po tym czasie odnotowano ją

Tabela II - Odpowiedź cytogenetyczna i molekularna w pierwszych 12 miesiącach leczenia ponatynibem chorych na PBSz w fazie przewleklej. Badanie PACE [22]

Table II - Cytogenetic and molecular response rates in chronic-phase CML patients after 12 months therapy with ponatinib. PACE trial [22]

\begin{tabular}{lccc}
$\begin{array}{l}\text { Odpowiedź cytogenetyczna } \\
\text { i molekularna }\end{array}$ & $\begin{array}{c}\text { Wszyscy } \\
\text { pacjenci }\end{array}$ & $\begin{array}{c}\text { Chorzy z opornością lub nietolerancją } \\
\text { dazatynibu albo nilotynibu }\end{array}$ & $\begin{array}{c}\text { Chorzy z mutacją } \\
\text { T315I }\end{array}$ \\
\hline MCyR", \% & 59 & 55 & 72 \\
CCyR, \% & 53 & 48 & 70 \\
MMR, \% & 39 & 33 & 58 \\
MR $4, \%$ & 22 & 19 & 34 \\
\hline " pierwszorzędowy punkt końcowy & &
\end{tabular}

pierwszorzędowy punkt końcowy 
Tabela III - Odsetki uzyskanych odpowiedzi cytogenetycznych u chorych na PBSz w fazie akceleracji, kryzy blastycznej i ALLPh(+) w zależności od średniej przyjmowanej dawki. Badanie PACE [24]

Table III - Cytogenetic response rates in patients with accelerated-phase CML and $\mathrm{Ph}(+) \mathrm{ALL}$ in relation to mean ponatinib dose ingested. PACE trial [24]

\begin{tabular}{lccc}
\hline Uzyskana odpowiedź cytogenetyczna & \multicolumn{3}{c}{ średnia dawka } \\
\cline { 2 - 4 } & $\geq 40,1 \mathrm{mg} / \mathrm{d}$ & $26,4-40,1 \mathrm{mg} / \mathrm{d}$ & 58 \\
\hline MCyR (\%) & 76 & 54 & 42 \\
CCyR (\%) & 70 & $\mathrm{mg} / \mathrm{d}$ \\
\hline
\end{tabular}

u 48\% pacjentów. MCyR utrzymało po 12 miesiącach leczenia $73 \%$ chorych [20]. Po 24 miesiącach obserwacji PFS wynosił $39 \%$, OS $72 \%$, a badanie zakończono z powodu progresji lub braku skuteczności odpowiednio u 21\% i 4\% chorych [20, 22].

\section{Wyniki u chorych na PBSz w fazie kryzy blastycznej i ALLPh(+)}

U chorych w fazie kryzy blastycznej PBSz MaHR uzyskano średnio po 4,1 tygodnia, MCyR po 1,9 miesiąca, a u chorych na ALLPh(+) MaHR po 2,9 tygodnia, a MCyR po 1 miesiącu. Średni czas trwania MaHR wynosił w tych grupach pacjentów odpowiednio 5 i 3 miesiące [20]. Po 12 miesiącach MaHR została utrzymana odpowiednio u $42 \%$ i $8 \%$ chorych, a MCyR u $66 \%$ i $22 \%$ chorych [20]. Po 24 miesiącach obserwacji PFS chorych z KB PBSz wynosił 11\%. PFS po 12 miesiącach leczenia chorych na ALLPh(+) wyniosło 7\%. Odsetek OS po 24 miesiącach obserwacji w obu grupach wyniósł 18\% [20, 22].
Z powodu progresji/ braku skuteczności leczenia badanie zakończono odpowiednio u 50\% i 0\% chorych z KB PBSz oraz u 53\% i $12 \%$ chorych na ALLPh(+) [20]. W wszystkich badanych grupach odsetki uzyskanych odpowiedzi w powyższych grupach pacjentów były mniejsze u chorych leczonych przed badaniem większą liczbą IKT (Tab. VI).

\section{Skuteczność ponatynibu w podgrupach z mutacjami genu BCR-ABL1}

W grupie chorych na PBSz w FA znaleźli się pacjenci z wykrywaną mutacją T315I ( $n=50$; grupa 1$)$, inną dodatkową mutacją oprócz T315I ( $\mathrm{n}=14$; grupa 2), mutacją inną niż T315I ( $n=67$; grupa 3) oraz chorzy bez mutacji wykrywanej w chwili kwalifikacji do badania ( $\mathrm{n}=136$; grupa 4). Po 15 miesiącach leczenia CCyR osiągnięto odpowiednio u 68\%, 57\%, 45\% i 38\% pacjentów z grupy 1, 2, 3 i 4. Pacjenci, u których wykryto mutację T315I, byli młodsi od pozostałych średnio o 9 lat

Tabela IV - Charakterystyka chorych na PBSz w fazie przewleklej po 4 latach obserwacji w badaniu PACE w zależności od liczby otrzymywanych uprzednio IKT [25]

Table IV - Characteristics of patients with chronic-phase CML in relation to number of previously received TKIs [25]. PACE trial, four-year follow-up [25]

\begin{tabular}{|c|c|c|c|c|}
\hline & $1 \mathrm{IKT}(\mathrm{n}=19)$ & $2 \operatorname{IKT}(\mathrm{n}=98)$ & $3 \operatorname{IKT}(\mathrm{n}=141)$ & $4 \mathrm{IKT}(\mathrm{n}=12)$ \\
\hline Średni wiek, lata & 52 & 58 & 63 & 67 \\
\hline $\begin{array}{l}\text { Średni czas od rozpoznania do pierwszej dawki leku } \\
\text { w badaniu, lata }\end{array}$ & 2,8 & 5,2 & 7,9 & 12,4 \\
\hline Średnia intensywność dawki, mg/d & 34,0 & 28,7 & 29,9 & 31,0 \\
\hline Mutacje wykryte przy kwalifikacji, \% & 68 & 51 & 43 & 75 \\
\hline T315I wykryta przy kwalifikacji, \% & 63 & 31 & 16 & 0 \\
\hline Poprzedni IKT, \%, imatynib/dazatynib/nilotynib/bosutynib & $68 / 21 / 5 / 5$ & $97 / 66 / 36 / 1$ & $100 / 96 / 96 / 7$ & $100 / 100 / 100 / 100$ \\
\hline Pacjenci nadal w badaniu, \% & 53 & 48 & 40 & 8 \\
\hline Pacjenci, którzy przerwali badanie, \% (n) & $47(9)$ & $52(51)$ & $60(85)$ & $92(11)$ \\
\hline \multicolumn{5}{|l|}{ Pierwotna przyczyna przerwania badania, \% } \\
\hline Działania niepożądane, \% (n) & $16(3)$ & $18(18)$ & $17(24)$ & $33(4)$ \\
\hline Wycofanie zgody & 5 & 11 & 11 & 25 \\
\hline Progresja choroby, \% (n) & $16(3)$ & $5(5)$ & $13(18)$ & 0 \\
\hline Brak skuteczności, \% (n) & 0 & $2(2)$ & $9(13)$ & $8(1)$ \\
\hline Zgon, \% (n) & 0 & $2(2)$ & $3(4)$ & $17(2)$ \\
\hline Inne $\mathrm{a}^{\mathrm{a}}$ & 11 & 13 & 8 & 8 \\
\hline Średni okres obserwacji, miesiące & 42,3 & 42,9 & 42,1 & 28,2 \\
\hline \multicolumn{5}{|l|}{ Odpowiedź na leczenie, n (\%) } \\
\hline MCyR & $12(75)^{b}$ & $69(70)$ & $69(49)$ & $7(58)$ \\
\hline CCyR & $12(75)^{b}$ & $63(64)$ & $63(45)$ & $4(33)$ \\
\hline MMR & $10(63)^{b}$ & $41(42)$ & $51(36)$ & 1 (8) \\
\hline $\mathrm{MR}^{4}$ & $6(38)^{b}$ & $30(31)$ & $38(27)$ & $1(8)$ \\
\hline $\mathrm{MR}^{4,5}$ & $4(25)^{b}$ & $22(22)$ & $34(24)$ & $1(8)$ \\
\hline
\end{tabular}


Tabela V - Wyniki leczenia ponatynibem chorych na PBSz w fazie akceleracji, kryzy blastycznej i ALLPh(+). Badanie PACE $[20,26]$

Table V - Efficacy of ponatinib in patients with accelerated- and blast-phase CML and Ph(+) ALL. PACE trial [20, 26]

\begin{tabular}{|c|c|c|c|c|}
\hline & MaHR, \% & MCyR, \% & CCyR, \% & MMR , \% \\
\hline \multicolumn{5}{|l|}{ Chorzy na PBSz w fazie akceleracji } \\
\hline Wszyscy chorzy $(n=83)$ & 55 & 39 & 24 & 16 \\
\hline Chorzy z opornością lub nietolerancją leczenia dazatynibem lub nilotynibem $(n=65)$ & 57 & 34 & 22 & 14 \\
\hline Chorzy z mutacją T315I $(\mathrm{n}=18)$ & 50 & 56 & 33 & 22 \\
\hline \multicolumn{5}{|l|}{ Chorzy na PBSz w fazie kryzy blastycznej lub ALLPh(+) } \\
\hline Wszyscy chorzy $(n=27)$ & 34 & 31 & 24 & $22^{* *}$ \\
\hline Chorzy z opornością lub nietolerancją leczenia dazatynibem lub nilotynibem $(\mathrm{n}=13)$ & 35 & 27 & 23 & 38 \\
\hline Chorzy z mutacją T315I $(n=14)$ & 33 & 35 & 26 & 7 \\
\hline
\end{tabular}

(średni wiek 52 lata), otrzymywali uprzednio średnio dwa IKT (pozostali średnio trzy IKT), a w toku badania przyjmowali większe średnie dawki ponatynibu [20]. Z powyższych powodów w analizie wielowariantowej obecność mutacji T315I nie była istotnym czynnikiem prognozującym osiągnięcie MCyR $[20,23]$. Stosowanie sekwencyjne różnych IKT niesie ze sobą ryzyko selekcji klonów komórek z nowymi mutacjami lub mutacjami złożonymi (według definicji to przynajmniej dwie mutacje występujące $\mathrm{w}$ tym samym allelu genu BCR/ABL1). Pojawienie się mutacji złożonych może być przyczyną oporności na szereg IKT [26], także na ponatynib, jak sugerowano $\mathrm{w}$ badaniach przedklinicznych [27]. Zidentyfikowano $12 \mathrm{klu}-$ czowych miejsc kinazy tyrozynowej ulegających często mutacjom także w przypadku wystąpienia mutacji złożonych. W stworzonym niedawno modelu in vitro przebadano szereg mutacji złożonych (najczęściej podwójnych) obejmujących miejsca kluczowe i stwierdzono, że ponatynib ma bardzo niewielką tylko aktywność wobec mutacji złożonych zawierających T315I (np. E255V/T315I, Q252H/T315I, T315I/M351T, T315I/F359V i T315I/H396R), gdzie wartość IC 50 przekraczała 6,5 raza stężenie ponatynibu w surowicy krwi uzyskiwane $\mathrm{u}$ chorych otrzymujących w badaniu PACE dawkę $45 \mathrm{mg} / \mathrm{d}$ [28]. Poza mutacją złożoną Y253H/E255V ponatynib skutecznie hamował wszystkie inne mutacje złożone niezawierające T315I w stężeniu uzyskiwanym w surowicy krwi podczas leczenia dawką $45 \mathrm{mg} / \mathrm{d}$ i $30 \mathrm{mg} / \mathrm{d}$. Oprócz wymienionej powyżej Y253H/E255V jedynie mutacje E255V/V299L i F317L/F359V nie były blokowane przez ponatynib w stężeniu osiąganym w surowicy krwi podczas leczenia dawką $15 \mathrm{mg} / \mathrm{d}$, co sugeruje, że stosowanie dawek mniejszych nie jest w stanie zapobiec powstawaniu nowych mutacji złożonych [28]. Autorzy wskazują, że badania profilu wrażliwości mutacji złożonych mogą być pomocnym żródłem informacji służących doborowi najbardziej skutecznego IKT. W badaniu PACE spośród 56 chorych na PBSz w FP, którzy zakończyli udział $\mathrm{w}$ badaniu, nową mutację wykryto u 5 , a u innych 5 obecna wcześniej mutacja znikła. Nowe mutacje wykryto u 5 spośród 25 chorych na PBSz w FA oraz u 23 spośród 42 chorych na PBSz w KB (u 2 obecne wcześniej mutacje zniknęły), którzy zakończyli udział $\mathrm{w}$ badaniu. Mutacje złożone pojawiły się u 16 chorych na PBSz w fazie kryzy blastycznej i ALLPh(+), u których mutacje pojedyncze wykrywano już w chwili kwalifikacji do badania [20]. W 15 przypadkach mutacje złożone dotyczyły tzw. miejsc kluczowych, jednak w żadnej z badanych grup nie wykryto mutacji, która byłaby przyczyną oporności na ponatynib.

Tabela VI - Odpowiedź na leczenie chorych na PBSz w fazie akceleracji, kryzy blastycznej i ALLPh(+) w zależności od liczby otrzymywanych uprzednio IKT [20]

Table VI - Efficacy of ponatinib in patients with accelerated- and blast-phase CML and $\mathrm{Ph}(+)$ ALL in relation to number of previously received TKIs [20]

PBSz w fazie akceleracji

\begin{tabular}{|c|c|c|c|c|}
\hline & $1 \mathrm{IKT}(\mathrm{n}=5)$ & $2 \mathrm{IKT}(\mathrm{n}=33)$ & $3 \mathrm{IKT}(\mathrm{n}=44)$ & $4 \mathrm{IKT}(\mathrm{n}=3)$ \\
\hline MaHR , \% & 80 & 61 & 50 & 67 \\
\hline MCyR, \% & 100 & 42 & 30 & 67 \\
\hline \multicolumn{5}{|c|}{ PBSz w fazie kryzy blastycznej i ALLPh(+) } \\
\hline & $1 \mathrm{IKT}(\mathrm{n}=9)$ & \multicolumn{2}{|r|}{$2 \operatorname{IKT}(\mathrm{n}=37)$} & $3 \mathrm{IKT}(\mathrm{n}=48)$ \\
\hline MaHR, \% & 33 & \multicolumn{2}{|r|}{41} & 29 \\
\hline MCyR, \% & 56 & \multicolumn{2}{|r|}{41} & 19 \\
\hline
\end{tabular}

" MaHR: obejmowała całkowitą odpowiedź hematologiczną (CHR) i odpowiedź bez obecnych cech białaczki (NeL: No evidence of Leukemia) definiowaną jako prawidłowa liczba leukocytów, bez blastów i promielocytów w rozmazie krwi obwodowej z sumarycznym odsetkiem mielocytów i metamielocytów lub odsetkiem bazofilów $<5 \%$, odsetek blastów w szpiku $\leq 5 \%$, bez zajęcia pozaszpikowego (w tym bez

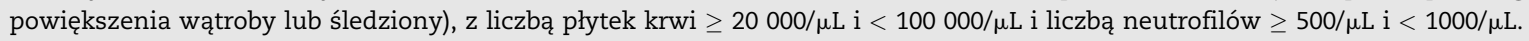




\section{Toksyczność ponatynibu}

Działania niepożądane były powodem przynajmniej jednej redukcji dawki ponatynibu w pierwszym roku leczenia w badaniu PACE u $64 \%$ chorych na PBSz w fazie przewlekłej. Mimo tego MCyR została utrzymana u 99\%, CCyR u 96\%, a MMR u 90\% pacjentów [22]. Do najczęściej obserwowanych niehematologicznych działań niepożądanych zwykle o ciężkości 1 i 2 stopnia należały: bóle brzucha (42\%), zaczerwienienie skóry (41\%) i zaparcia (37\%). Małopłytkowość (43\%), neutropenia (25\%) i niedokrwistość (24\%) występujące zazwyczaj w 3 i 4 stopniu ciężkości były najczęstszymi hematologicznymi działaniami niepożądanymi (Tab. VII) [22, 25]. Zapalenie trzustki wystąpiło u 6\% (29 z 449) chorych (w większości o ciężkości 3. i 4. stopnia); pojawiało się średnio po 14 dniach terapii i ustępowało zwykle w okresie 1 tygodnia po modyfikacji dawkowania ponatynibu. Jeden nawrót odnotowano u 3 pacjentów, a u jednego chorego nawrotów było kilka. Leczenia zaprzestano $\mathrm{z}$ tego powodu u jednego pacjenta [20]. Ciężkie zdarzenia niepożądane po 4 latach obserwacji obejmowały zapalenie płuc (5\%), zapalenie trzustki (7\%) i niedokrwienie mięśnia sercowego (5\%) [25]. Działania niepożądane ustępowały po redukcji dawki ponatynibu lub czasowym jego odstawieniu [20, 22, 29]. Po roku obserwacji leczenia zaprzestano $\mathrm{z}$ powodu pojawiających się działań niepożądanych leku u 13\% wszystkich chorych i odpowiednio u $11 \%, 16 \%$ i $6 \%$ chorych na $\mathrm{PBSz}$ $\mathrm{w}$ fazie przewlekłej, akceleracji, kryzy blastycznej i ALLPh+ [20]. Po 4 latach obserwacji u chorych na PBSz w fazie przewlekłej wykazano, że częstość zdarzeń niepożądanych w stopniu 3. i 4. wzrasta wraz z liczbą IKT stosowanych przed kwalifikacją do badania (Tab. IV) [25]. Po rocznym okresie obserwacji odnotowano 18 zgonów (2\%, 2\%, 10\% i 16\% odpowiednio u chorych na PBSz w fazie przewlekłej, akceleracji, kryzy blastycznej i ALLPh+). Stosowanie ponatynibu uznano za prawdopodobną przyczynę 5 z nich [20]. Liczba zgonów chorych na PBSz w fazie przewlekłej po 4 latach obserwacji wyniosła 8 (3\%) [25]. Zakrzepica tętnicza i żylna, zawał serca, konieczność pilnych zabiegów rewaskularyzacyjnych, ciężka niedrożność naczyń obwodowych, stenoza dużych naczyń mózgu i udar mózgu wystąpiły u ok. $27 \%$ chorych w badaniach fazy I i II niezależnie od obecnych czynników ryzyka chorób sercowo-naczyniowych, także u pacjentów przed 50. rokiem życia. Niedrożność naczyń występuje zwykle w pierwszych 2 tygodniach leczenia ponatynibem, może dotyczyć wielu miejsc i mieć charakter nawrotowy [14]. Po 4 latach obserwacji w badaniu PACE epizody niedrożności naczyń odnotowano u $19 \%$ chorych (u 14\% jako ciężkie zdarzenie niepożądane) w postaci epizodów sercowo-naczyniowych u 10\% (u 7\% ciężkie), naczyniowo-mózgowych u 7\% (u 5\% ciężkie) i niedrożności tętnic obwodowych u 7\% (u 4\% ciężkie). Epizody zakrzepicy żylnej wystąpiły u 5\% pacjentów (u 3\% jako ciężkie) [25]. Większe dawki leku, wiek > 50 lat, długotrwała choroba, obecność czynników ryzyka choroby niedokrwiennej serca (cukrzyca, hyperlipidemia, nadciśnienie), przebyty epizod niedokrwienia, większa liczba płytek krwi i większy odsetek neutrofilów w chwili rozpoczęcia leczenia zwiększały ryzyko powikłań zatorowo-zakrzepowych [20,25]. Częstość epizodów niedrożności tętnic wzrastała wraz z liczbą IKT stosowanych

Tabela VII - Najczęściej występujące dzialania niepożądane ponatynibu. Badanie PACE [22, 25] Table VII - Most frequently occurring adverse events of ponatinib. PACE trial [22, 25]

Działanie niepożądane

Po 2 latach obserwacji [20]

Po 4 latach obserwacji [25]

$$
\begin{aligned}
& \text { Wszystkie stopnie } \\
& \text { Częstość }>20 \%
\end{aligned}
$$

3./4. st.

3./4. st.

Częstość > 10\%

$\begin{array}{ll}\text { Małopłytkowość, \% } & 43 \\ \text { Ból brzucha } & 42 \\ \text { Zaczerwienienie skóry } & 41 \\ \text { Zaparcia } & 37 \\ \text { Bóle głowy } & 37 \\ \text { Suchość skóry } & 36 \\ \text { Zmęczenie } & 30 \\ \text { Gorączka } & 29 \\ \text { Nudności } & 29 \\ \text { Bóle stawów } & 29 \\ \text { Nadciśnienie } & 28 \\ \text { Neutropenia } & 25 \\ \text { Niedokrwistość } & 24 \\ \text { Bóle mięśni } & 21 \\ \text { Biegunka } & 21 \\ \text { Wymioty } & 21 \\ \text { Wzrost stężenia lipazy } & 21\end{array}$

43
42
41
37
37
36
30
29
29
29
28
25
24
21
21
21
21

36
9
4
2
2
2
3
2
2
2
11
22
12
$<1$
2
1
12

35

10

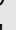

b.d.

b.d.

2 b.d.

$2 \quad$ b.d.

3 b.d.

2 b.d.

2 b.d.

2 b.d.

$11 \quad 13$

$22 \quad 17$

12 b.d.

1 b.d.

2 b.d.

1 b.d.

$12 \quad 12$

Ciężkie zdarzenia niepożądane ponatynibu występujące $u \geq 5 \%$ chorych

Zapalenie płuc

Zapalenie trzustki

7

Angina pectoris

b.d.

5

b.d. = brak danych 
przed badaniem i wynosiła u chorych otrzymujących 1, 2, 3 i 4 IKT odpowiednio $32 \%$ (6/19), 26\% (25/98), 28\% (39/141) i $42 \%$ (5/12). Skorygowana wobec narażenia na czynniki ryzyka częstość nowych epizodów niedrożności u tych chorych wyniosła odpowiednio 11,75; 10,4; 12,6 i 33,3 zdarzeń na 100 pacjento-lat [25]. Niewydolność serca pod postacią zastoinowej niewydolności krążenia, niewydolności prawokomorowej i krążeniowo-oddechowej, obrzęku płuc, wstrząsu kardiogennego i zmniejszonej frakcji wyrzutowej lewej komory wystąpiła u $8 \%$ chorych (u 5\% jako ciężka, u ok. 50\% w stopniu ciężkości 1. i 2.) [20]. Zwiększenie stężenia ALT i AST odnotowano u 53\% i $41 \%$ chorych (wszystkie stopnie ciężkości) w tym u $8 \%$ i $4 \%$ pacjentów w stopniu 3. i 4 . Zaburzenie to było odwracalne u 95\% pacjentów, u 2 chorych na $\mathrm{PBSz}$ w fazie kryzy blastycznej lub ALLPh+ doszło do śmiertelnej w skutkach niewydolności wątroby [14].

\section{Wyniki jednoośrodkowego badania II fazy u chorych na PBSz w FP z opornością lub nietolerancją jednego IKT}

Do badania zakwalifikowano 5 chorych $\mathrm{z}$ opornością lub nietolerancją imatynibu $(\mathrm{n}=3)$ lub dazatynibu $(\mathrm{n}=2)$ [30]. Niepowodzenie leczenia definiowano zgodnie $\mathrm{z}$ rekomendacjami ELN. Pierwszorzędowym celem badania było uzyskanie MCyR w 6. miesiącu leczenia. Drugorzędowe cele obejmowały uzyskanie odpowiedzi cytogenetycznej w innych punktach czasowych, osiągnięcie odpowiedzi molekularnej i zbadanie profilu toksyczności. Do badania zakwalifikowano 5 chorych, zanim zostało zamknięte zgodnie z sugestią FDA. Powodem kwalifikacji do badania była utrata CCyR $(\mathrm{n}=1)$, brak CCyR po 18 miesiącach leczenia IKT $(n=1)$, brak CCyR po 18 miesiącach leczenia IKT z wystąpieniem mutacji T315I ( $n=1)$, wystąpienie mutacji T315I $(n=1)$ oraz brak częściowej odpowiedzi cytogenetycznej (PCyR) po 12 miesiącach leczenia IKT $(n=1)$. U jednego chorego w chwili kwalifikacji stwierdzono nadciśnienie tętnicze. CCyR uzyskało 4 spośród 5 chorych po 3 i po 6 miesiącach leczenia ponatynibem. Po 12 miesiącach leczenia MMR uzyskano u 2, $\mathrm{MR}^{4,5}$ u jednego i znaczną redukcję liczby transkryptu u jednego chorego. Najlepszą skumulowaną odpowiedzią po średnim okresie obserwacji 22 miesięcy była $\mathrm{MR}^{4,5}$ uzyskana u 4 chorych i PCyR u jednego pacjenta. Działania niepożądane w 3. lub 4. stopniu nasilenia obejmowały nadciśnienie $(\mathrm{n}=2)$, rak kolczystokomórkowy skóry $(n=1)$, zwiększenie stężenia: lipazy $(n=2)$, amylazy $(n=1)$, ALT $(n=2)$, AST $(n=2)$, małopłytkowość $(\mathrm{n}=1)$ i neutropenia $(\mathrm{n}=1)$. Nadciśnienie pojawiło się u 4 chorych i było dobrze kontrolowane lekami. Nie odnotowano żadnego epizodu zakrzepicy tętniczej ani żylnej. Nawracająca małopłytkowość i neutropenia stopnia 3. lub 4. pojawiała się u chorego, który nie uzyskał CCyR i ustępowała po czasowym odstawieniu leku. Dawkę redukowano u wszystkich pacjentów (chorych kontynuowało leczenie dawką $30 \mathrm{mg} / \mathrm{d}$, a 3 dawką $15 \mathrm{mg} / \mathrm{d}$ ). Podsumowując, $80 \%$ chorych osiągnęło przynajmniej CCyR i MR ${ }^{4.0}$, które utrzymywały się przez relatywnie długi czas obserwacji [30]. Wyniki, choć dotyczą bardzo małej liczby chorych, potwierdzają skuteczność ponatynibu w leczeniu chorych z opornością lub nietolerancją uprzedniego leczenia jednym IKT.

\section{Badanie II fazy u chorych z noworozpoznaną PBSz}

Do badania zakwalifikowano 51 pacjentów z PBSz rozpoznaną nie dawniej niż 6 miesięcy wstecz. Przez pierwszych 11 miesięcy pacjenci otrzymywali dawkę $45 \mathrm{mg} / \mathrm{d}$ ponatynibu ( $n=43)$, następnie wszyscy nowo kwalifikowani do badania otrzymywali dawkę $30 \mathrm{mg} / \mathrm{d}(\mathrm{n}=8)$. Po opublikowaniu 06.10.2013 przez FDA ostrzeżenia o epizodach niedrożności naczyń związanych z ponatynibem u wszystkich pacjentów rozpoczęto podawanie aspiryny w dawce $81 \mathrm{mg} / \mathrm{d}$ oraz zredukowano dawki leku do $30 \mathrm{mg} / \mathrm{d}$ i do $15 \mathrm{mg} / \mathrm{d}$. Badanie zostało zakończone zgodnie $\mathrm{z}$ sugestią FDA 18.06.2014 r. z powodu zwiększonego ryzyka wywoływania przez ponatynib powikłań zatorowo-zakrzepowych. Średni okres obserwacji wyniósł 20,9 miesiąca (14,9-25,2). 43 (94\%) spośród ocenianych 46 chorych uzyskało CCyR w 6. miesiącu leczenia. Najczęstsze działania niepożądane obejmowały zmiany skórne $(\mathrm{n}=35 ; 69 \%)$ i zwiększenie stężenia lipazy ( $\mathrm{n}=32 ; 63 \%$ ). Zaburzenia sercowo-naczyniowe (głównie nadciśnienie) odnotowano u 25 (49\%) pacjentów, a toksyczność hematologiczną w stopniu 3. lub 4. u 15 (29\%). U 5 chorych (10\%) doszło do powikłań naczyniowych w obrębie mózgu lub niedrożności naczyń obwodowych. U 43 (85\%) chorych leczenie czasowo przerywano, a u 45 (88\%) konieczna była redukcja dawki leku [31].

\section{Badanie III fazy u chorych z noworozpoznaną PBSz}

EPIC było wieloośrodkowym, międzynarodowym, randomizowanym, otwartym badaniem III fazy porównującym ponatinib w dawce $45 \mathrm{mg} / \mathrm{d} \mathrm{z}$ imatynibem w dawce $400 \mathrm{mg} / \mathrm{d}$ $\mathrm{u}$ chorych $\mathrm{z}$ noworozopoznaną PBSz w FP [32]. Nie jest możliwa ocena żadnego $\mathrm{z}$ założonych celów pierwszorzędowych badania, gdyż 18 października 2013 r. badanie zakończono, zgodnie $\mathrm{z}$ sugestią FDA, z powodu podwyższonego ryzyka zakrzepicy tętniczej u chorych leczonych ponatynibem. Dane z 01.04.2014 umożliwiają analizę czterech punktów końcowych: odsetka chorych $\mathrm{z}$ redukcją BCR/ABL1 do $<10 \%$ w 3. miesiącu leczenia, odsetek uzyskanych MMR, $\mathrm{MR}^{4}$ i $\mathrm{MR}^{4,5}$ przynajmniej po 3, 6, 9, 12 miesiącach i kiedykolwiek, czas do odpowiedzi, odsetek CCyR w 6, 12 miesiącu i kiedykolwiek oraz bezpieczeństwo leku. Do chwili zakończenia badania zrandomizowano 307 pacjentów, wśród których większy odsetek chorych z czynnikami ryzyka chorób sercowo -naczyniowych (nadciśnienie, hipercholesterolemia, cukrzyca, otyłość, palenie tytoniu) znalazł się w grupie leczonej ponatynibem (63\%) niż imatynibem (52\%). Czternastu chorych $\mathrm{w}$ ramieniu $\mathrm{z}$ ponatynibem i dwóch $\mathrm{w}$ ramieniu z imatynibem zaprzestało leczenia wskutek działań niepożądanych. Redukcję poziomu transkryptu BCR/ABL1 do $<10 \%$ w 3. miesiącu leczenia uzyskało istotnie więcej (94\%) leczonych ponatynibem niż otrzymujących imatynib (68\%). Odsetki odpowiedzi molekularnych (MMR, $\mathrm{MR}^{4}, \mathrm{MR}^{4,5}$ ) były istotnie większe wśród pacjentów otrzymujących ponatynib w każdym punkcie czasowym i np. w 9. miesiącu wynosiły odpowiednio dla ponatynibu i imatynibu: $86 \%$ i $33 \%$ (MMR), $64 \%$ i $4 \%\left(M^{4}\right)$ oraz $32 \%$ i $0 \%\left(M^{4,5}\right)$. Najczęstsze ( $u \geq 25 \%$ chorych) działania niepożądane ponatynibu wszystkich stopni nasilenia obejmowały: zaczerwienienie skóry (38\%), ból brzucha (36\%), ból głowy (33\%), 
zaparcie (27\%), zwiększenie stężenia lipazy (27\%), ból mięśni (26\%) i małopłytkowość (25\%), która u 12\% miała nasilenie stopnia 3. lub 4. Neutropenia w stopniu 3 lub 4. wystąpiła u 3\% leczonych ponatynibem. Ciężkie zdarzenia niepożądane, które wystąpiły u $\geq 3$ chorych otrzymujących ponatynib, obejmowały: zapalenie trzustki $(n=5)$, migotanie przedsionków $(n=3)$ i małopłytkowość $(n=3)$. Zakrzepica tętnicza wystąpiła u $11(7 \%)$ otrzymujących ponatynib i $3(2 \%)$ leczonych imatynibem. Oceniono je jako ciężkie u 10 leczonych ponatynibem i u 1. chorego otrzymującego imatynib. Ciężka zakrzepica żylna wystąpiła u jednego pacjenta leczonego ponatynibem. U 10 spośród 11 chorych z zakrzepicą tętniczą otrzymujących ponatynib i u 2 spośród 3 leczonych imatynibem występował przynajmniej jeden czynnik ryzyka choroby sercowo-naczyniowej.

\section{Wskazania i sposób dawkowania ponatynibu}

Ponatynib został zarejestrowany przez Amerykańską Agencję ds. Żywności i Leków (FDA) 14.12.2012 r. Raporty o epizodach niedrożności naczyń związanych ze stosowaniem ponatynibu były przyczyną wstrzymania przez FDA 18.10.2013 r. rekrutacji do badania EPIC oceniającego skuteczność ponatynibu w leczeniu pierwszego wyboru u chorych na PBSz w fazie przewlekłej oraz zawieszenia dystrybucji leku w USA (31.10.2013). Ponowna rejestracja, z określonymi obostrzeniami miała miejsce w styczniu 2014 [14, 15]. Lek zarejestrowano do leczenia dorosłych chorych, u których mutacja T315I wykrywana jest w przebiegu PBSz (dotyczy wszystkich faz choroby) lub ALLPh(+) oraz dla chorych z opornością lub nietolerancją leczenia PBSz dazatynibem albo nilotynibem lub ALLPh(+) dazatynibem, u których kolejne leczenie imatynibem nie jest optymalną opcją terapeutyczną.

Zalecana dawka początkowa wynosi $45 \mathrm{mg} / \mathrm{d}$ przyjmowana doustnie raz dziennie. Lek może być przyjmowany z pokarmem, nie należy dzielić ani rozpuszczać tabletki. Rekomendowana jest redukcja dawki do $30 \mathrm{mg} / \mathrm{d} \mathrm{u}$ chorych na PBSz we wszystkich fazach, którzy uzyskali przynajmniej MCyR [14]. Każda redukcja dawki ponatynibu o $15 \mathrm{mg}$ zmniejsza ryzyko tętniczych powikłań zakrzepowych o ok. $40 \%$ [24].

\section{Miejsce ponatynibu w terapii PBSZ i ALLPh(+)}

Ponatynib, będąc inhibitorem obdarzonym szerokim spektrum oddziaływania na szereg kinaz tyrozynowych (tzw. pan-inhibitor) oraz siłą blokowania kinazy bcr-abl w warunkach in vitro przewyższającą dazatynib, jest niezwykle skutecznym lekiem. Większość chorych z noworozpoznaną PBSz w FP leczonych ponatynibem uzyskuje szybko CCyR oraz MMR, jednak z uwagi na ryzyko powikłań zakrzepowych w leczeniu pierwszego wyboru należy rozważyć inne IKT [31]. W leczeniu kolejnego rzutu u chorych na PBSz w FP poddanych uprzednio długotrwałej terapii pozostałymi IKT ponatynib umożliwia uzyskanie po 12 miesiącach leczenia MCyR u 56\% pacjentów, CCyR osiągana jest w tym czasie u prawie połowy, a MMR u około jednej trzeciej chorych. Lek ten wykazał swoją skuteczność także u chorych na PBSz w FA oraz na PBSz w KB lub ALLPh(+), doprowadzając do uzyskania MaHR u odpowiednio ponad 50\% i 34\% pacjentów. We wszystkich grupach badanych odpowiedzi uzyskiwane były niezależnie od faktu oporności na nilotynib albo dazatynib lub występowania mutacji T315I. Zastosowanie ponatynibu u chorych z wykrytą mutacją T315I w przebiegu PBSz lub ALLPh(+) nie budzi żadnych wątpliwości, gdyż alternatywną opcją terapeutyczną w takiej sytuacji jest alogeniczna transplantacja komórek hemopoetycznych obciążona istotnym ryzykiem zgonu. Zastosowanie tego leku jako trzeciego IKT W sekwencji imatynib, IKT2G, ponatynib w porównaniu z sekwencją leczenia: imatynib, IKT2G, inny IKT2G stwarza, według porównania dokonanego $\mathrm{w}$ oparciu o systematyczny przegląd literatury i wyników wybranych 8 badań klinicznych, zdecydowanie większe szanse na osiągnięcie CCyR (54-67\% w porównaniu z 20-26\%) [33]. W obliczu jednak konieczności dokonania wyboru kolejnego leczenia poza wynikiem analizy mutacji domeny kinazy abl należy wziąć pod uwagę przewidywane korzyści oraz potencjalne zagrożenia związane z wdrożeniem ponatynibu zwłaszcza u pacjentów obciążonych chorobami współistniejącymi. Niewielka specyficzność tego leku w odniesieniu do kinazy bcr/abl i zdolność ponatynibu do blokowania wielu innych kinaz tyrozynowych wiąże się ze zwiększonym ryzykiem wywoływania szeregu działań niepożądanych. Na podstawie analizy częstości i nasilenia ich występowania w trakcie badania EPIC FDA sformułowała ostrzeżenie mówiące o zwiększonym ryzyku niedrożności naczyń, niewydolności serca i toksyczności wątrobowej u chorych przyjmujących ponatynib. Metaanaliza 10 badań klinicznych obejmująca 3043 pacjentów dotycząca związku między stosowanymi rutynowo w leczeniu PBSz IKT a zdarzeniami niepożądanymi sercowo-naczyniowymi wykazała, że ryzyko niedrożności naczyń jest zwiększone u chorych otrzymujących dazatynib (OR 3,86; 95\% CI 1,33-11,18), nilotynib (OR 3,42; 95\% CI 2,075,63 ) i ponatynib (OR 3,47; 95\% CI 1,23-9,78) w porównaniu z leczonymi imatynibem. Nie stwierdzono istotnych różnic z grupą leczonych bosutynibem (OR 2,77; 95\% CI 0,39-19,77) [34]. Z tego powodu zalecane jest ścisłe kontrolowanie pacjentów pod kątem wystąpienia powyższych powikłań. Leczenie powinno być kontynuowane do pojawienia się progresji choroby lub nieakceptowalnej toksyczności z zaleceniem modyfikacji dawek w przypadku działań niepożądanych. Przed wdrożeniem ponatynibu, a także w trakcie leczenia rekomendowane jest sprawdzanie stanu układu krążenia oraz wykonywanie badań w kierunku cukrzycy i hiperlipidemii. Ponatynib należy stosować z dużą ostrożnością u chorych z objawami niewydolności krążenia, z czynnikami ryzyka choroby niedokrwiennej serca, nie powinien być podawany chorym po zawale serca i udarze mózgu, chyba że korzyści z jego stosowania przewyższają potencjalne ryzyko. Leczenie ponatynibem należy natychmiast wstrzymać u chorych, u których istnieje podejrzenie niedrożności tętnic lub żył, toksyczności wątrobowej lub zawału serca [14]. Niezwykle istotne znaczenie ma modyfikacja stylu życia, profilaktyka i odpowiednie leczenie mające na celu niwelowanie negatywnych skutków obecności czynników ryzyka u chorych poddawanych terapii ponatynibem. Podsumowując, stosowanie ponatynibu wymaga 
wnikliwej analizy chorób współistniejących, umiejętnego modyfikowania czynników ryzyka występujących u pacjenta, dużej ostrożności ze względu na profil bezpieczeństwa leku oraz modyfikowania dawki w obliczu pojawiających się działań niepożądanych. Lek ten stanowi niezwykle wartościową opcję leczenia dla pacjentów z wykrytą mutacją T315I w przebiegu PBSz lub ALLPh(+) oraz dla chorych z opornością lub nietolerancją dotychczasowego leczenia, dla których dotychczasowe opcje terapeutyczne obejmowały terapię sekwencyjną kolejnym IKT, alogeniczną transplantację komórek krwiotwórczych lub udział w badaniach eksperymentalnych z nowymi cząsteczkami.

\section{Konflikt interesu/Conflict of interest}

TS pobierał honoraria za konsultacje od firm Novartis, BMS, Adamed, Angelini.

\section{Finansowanie/Financial support}

Nie występuje.

\section{Etyka/Ethics}

Treści przedstawione $\mathrm{w}$ artykule są zgodne $\mathrm{z}$ zasadami Deklaracji Helsińskiej, dyrektywami EU oraz ujednoliconymi wymaganiami dla czasopism biomedycznych.

\section{PIŚ M I E N N ICT W O/R E FERENCES}

[1] Melo JV. The molecular biology of chronic myeloid leukemia. Leukemia 1996;10:751-756.

[2] Druker BJ, Talpaz M, Resta DJ, et al. Efficacy and safety of a specific inhibitor of the BCR-ABL tyrosine kinase in chronic myeloid leukemia. N Engl J Med 2001;344:1031-1037.

[3] Deininger M, O'Brien SG, Guilhot F, et al. International Randomized Study of Interferon Vs STI571 (IRIS) 8-Year Follow up: Sustained Survival and Low Risk for Progression or Events in Patients with Newly Diagnosed Chronic Myeloid Leukemia in Chronic Phase (CML-CP) Treated with Imatinib. Blood 2009. ASH Abstract: 1126.

[4] Goldman JM. Ponatinib for chronic myeloid leukemia. N Engl J Med 2012;367(22):2148-2149.

[5] Cortes J, Radich J, Mauro MJ. Clinical roundtable monograph: emerging treatment options for TKI-resistant chronic myelogenous leukemia. Clin Adv Hematol Oncol 2012;10(10 Suppl 19):1-16.

[6] Baccarani M, Deininger MW, Rosti G, et al. European LeukemiaNet recommendations for the management of chronicmyeloid leukemia: 2013. Blood 2013;122: 872-884.

[7] Hochhaus A, Baccarani M, Deininger M, et al. Dasatinib induces durable cytogenetic responses in patients with chronic myel-ogenous leukemia in chronic phase with resistance or intolerance to imatinib. Leukemia 2008;22:1200-1206.

[8] Kantarjian H, Pasquini R, Levy V, et al. Dasatinib or highdose imatinib for chronic-phase chronic myeloid leukemiaresistant to imatinib at a dose of 400 to 600 milligrams daily: two-year follow-up of a randomized phase 2 study (START-R). Cancer 2009;115:4136-4147.

[9] Kantarjian HM, Giles FJ, Bhalla KN, et al. Nilotinib is effective in patients with chronic myeloid leukemia in chronicphase after imatinib resistance or intolerance: 24month follow-up results. Blood 2011;117:1141-1145.

[10] National Comprehensive Cancer Network. NCCN clinical practice guidelines in oncology: chronic myelogenous leukemia (version 3.2014). 2014. http://www.nccn.org/ professionals/physician_gls/pdf/cml.pdf. Accessed 11 April 2014.

[11] Cortes JE, Kantarjian H, Shah NP, et al. Ponatinib in refractory Philadelphia chromosome-positive leukemias. N Engl J Med 2012;367(22):2075-2088.

[12] O'Hare T, Eide CA, Deininger MWN. Bcr-Abl kinase domain mutations, drugresistance, and the road to a cure for chronic myeloid leukemia. Blood 2007;110:2242-2249.

[13] O'Hare T, Shakespeare WC, Zhu X, et al. AP24534, a panBCRABL inhibitor for chronic myeloid leukemia, potently inhibits the T315I mutant and overcomes mutation-based resistance. Cancer Cell 2009;16(5):401-412.

[14] Ariad Pharmaceuticals Inc. Iclusig ${ }^{\circledR}$ (ponatinib) tablets for oral use: prescribing information; 2013. http://www. accessdata.fda. gov/drugsatfda_docs/label/2013/ 203469s007s008lbl.pdf. Accessed 11 April 2014.

[15] European Medicines Agency. Iclusig (ponatinib): summary of product characteristics; 2014. http://www.ema.europa. eu/docs/en_GB/document_library/EPAR__Product_Information/human/002695/WC500145646.pdf. Accessed 11 April 2014.

[16] European Medicines Agency. Assessment report: Iclusig (ponatinib); 2013. http://www.ema.europa.eu/docs/en_GB/ document_library/EPAR_-_Public_assessment_report/ human/002695/WC500145648.pdf. Accessed 11 April 2014.

[17] Narasimhan NI, Dorer DJ, Niland K, et al. Effects of food on the pharmacokinetics of ponatinib in healthy subjects. J Clin Pharm Ther 2013;38(6):440-444.

[18] Narasimhan NI, Dorer DJ, Niland K, et al. Effects of ketoconazole on the pharmacokinetics of ponatinib in healthy subjects. J Clin Pharmacol 2013;53(9):974-981.

[19] Sonnichsen D, Dorer DJ, Cortes J, et al. Analysis of the potential effect of ponatinib on the QTc interval in patients with refractory hematological malignancies. Cancer Chemother Pharmacol 2013;71(6):1599-1607.

[20] Cortes JE, Kim D-W, Pinilla-Ibarz J, et al. A phase 2 trial of ponatinib in Philadelphia chromosome-positive leukemias. N Engl J Med 2013;369(19):1783-1796 (plus supplementary appendix).

[21] Cortes JE, Kim D-W, Pinilla-Ibarz J, et al. A pivotal phase 2 trial of ponatinib in patients with chronic myeloid leukemia (CML) and Philadelphia chromosome-positive acute lymphoblastic leukemia ( $\mathrm{Ph}+\mathrm{ALL}$ ) resistant or intolerant to dasatinib or nilotinib, or with the T315I BCR-ABL mutation: 12-month follow-up of the PACE trial [abstract no. 163 plus oral]. Blood 2012;120(21).

[22] Cortes JE, Kim D-W, Pinilla-Ibarz J, et al. Long-Term Followup of Ponatinib Efficacy and Safety in the Phase 2 PACE Trial. ASH 2014. Abstract 3135.

[23] Mauro MJ, Cortes JE, Kim D-W, et al. Multivariate analyses of the clinical and molecular parameters associated with efficacy and safety in patients with chronic myeloid leukemia (CML) and Philadelphia chromosome-positive acute lymphoblastic leukemia (Ph? ALL) treated with ponatinib in the PACE trial [abstract no. 3747 plus poster] Blood 2012;120(21).

[24] Pinilla-Ibarz J, Cortes JE, Kim D-W, et al. Clinical impact of dose modification on response to ponatinib in patients with chronic phase chronic myeloid leukemia (CP-CML) [abstract no. 4007 plus poster]. Blood 2013;122(21). 
[25] Hochhaus A, Cortes JE, Kim D-W, et al. Efficacy and Safety of Ponatinib in CP-CML Patients By Number of Prior Tyrosine Kinase Inhibitors: 4-Year Follow-up of the Phase 2 PACE Trial. ASH 2015. Abstract 4025.

[26] Shah NP, Skaggs BJ, Branford S, Hughes TP, Nicoll JM, Paquette RL, et al. Sequential ABL kinase inhibitor therapy selects for compound drug-resistant BCR-ABL mutations with altered oncogenic potency. J Clin Invest 2007;117:25622569 [PubMed: 17710227].

[27] O'Hare O'Hare T, Shakespeare WC, Zhu X, et al. AP24534, a pan-BCR-ABL inhibitor for chronic myeloid leukemia, potently inhibits the T315I mutant and overcomes mutation-based resistance. Cancer Cell 2009;16:401-412 [PubMed: 19878872].

[28] Zabriskie MS, Eide CA, Tantravahi SK, et al. BCR-ABL1 Compound Mutations Combining Key Kinase Domain Positions Confer Clinical Resistance to Ponatinib in Ph Chromosome-Positive Leukemia. Cancer Cell 2014 September 8;26(3):428-442.

[29] Hochhaus A, Kim D-W, Pinilla-Ibarz J, et al. Molecular responses with ponatinib in patients with Philadelphia chromosome positive $(\mathrm{Ph}+)$ leukemia: results from the PACE trial [abstract no. 3763 plus poster]. Blood 2012;120(21).
[30] Sanford D, Kantarjian H, Skinner J, et al. Phase II trial of ponatinib in patients with chronic myeloid leukemia resistant to one previous tyrosine kinase inhibitor. Haematologica 2015;100:e495.

[31] Jain P, Kantarjian H, Jabbour E, et al. Ponatinib as first-line treatment for patients with chronic myeloid leukaemia in chronic phase: a phase 2 study. The Lancet Hematology 2015;2(9):e376-e383.

[32] Lipton J, Chuah C, Guerci-Bresler A, et al. Epic: A Phase 3 Trial of Ponatinib Compared with Imatinib in Patients with Newly Diagnosed Chronic Myeloid Leukemia in Chronic Phase (CP-CML). ASH 2014. Abstract 519.

[33] Lipton J, Shah D, Tongbram V, et al. Comparative Efficacy Among 3rd Line Post-Imatinib Chronic Phase-Chronic Myeloid Leukemia (CP-CML) Patients after Failure of Dasatinib or Nilotinib Tyrosine Kinase Inhibitors. ASH 2014. Abstract 4551.

[34] Douxfils J, Haguet H, Mullier F, et al. Association Between BCR-ABL Tyrosine Kinase Inhibitors for Chronic Myeloid Leukemia and Cardiovascular Events, Major Molecular Response, and Overall SurvivalA Systematic Review and Meta-analysis. JAMA Oncol 2016. http://dx.doi.org/10.1001/ jamaoncol.2015.5932. Published online February 04. 